\title{
Holm, Lars
}

\section{Researching extended schooling ethnographically - with Danish all-day schools as examples \\ International journal for research on extended education : IJREE 3 (2015) 1, S. 39-51}

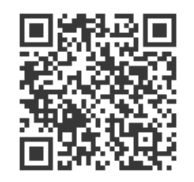

Quellenangabe/ Reference:

Holm, Lars: Researching extended schooling ethnographically - with Danish all-day schools as examples - In: International journal for research on extended education : IJREE 3 (2015) 1, S. 39-51 - URN: urn:nbn:de:0111-pedocs-229925 - DOI: 10.25656/01:22992

https://nbn-resolving.org/urn:nbn:de:0111-pedocs-229925

https://doi.org/10.25656/01:22992

in Kooperation mit / in cooperation with:

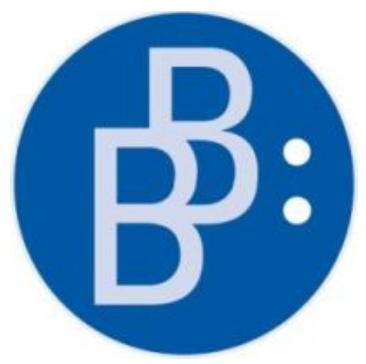

https://www.budrich.de

\section{Nutzungsbedingungen}

Dieses Dokument steht unter folgender Creative Commons-Lizenz:

http://creativecommons.org/licenses/by-nc-nd/3.0/de/deed - Sie dürfen das Werk bzw. den Inhalt unter folgenden Bedingungen vervielfältigen, verbreiten und öffentlich zugänglich machen: Sie müssen den Namen des Autors/Rechteinhabers in der von ihm festgelegten Weise nennen. Dieses Werk bzw. dieser Inhalt darf nicht für kommerzielle Zwecke verwendet werden und es darf nicht bearbeitet, abgewandelt oder in anderer Weise verändert werden.

Mit der Verwendung dieses Dokuments erkennen Sie die Nutzungsbedingungen an.

\section{Terms of use}

This document is published under following Creative Commons-License: http://creativecommons.org/licenses/by-nc-nd/3.0/de/deed.en - You may copy, distribute and transmit, adapt or exhibit the work in the public as long as you attribute the work in the manner specified by the author or licensor. You are not allowed to make commercial use of the work or its contents. You are not allowed to alter, transform, or change this work in any other way.

By using this particular document, you accept the above-stated conditions of use.

\section{Kontakt / Contact:}

\section{peDOCS}

DIPF | Leibniz-Institut für Bildungsforschung und Bildungsinformation

Informationszentrum (IZ) Bildung

E-Mail: pedocs@dipf.de

Internet: www.pedocs.de 


\section{IJREE}

International ouria a for
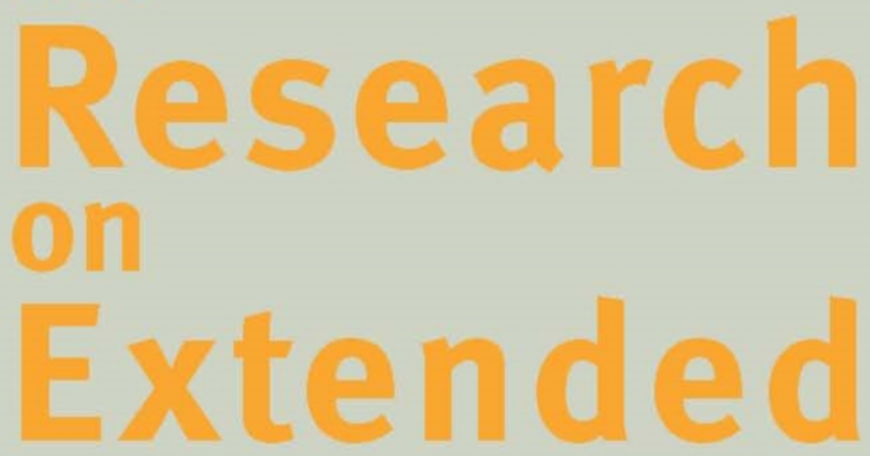
Edu cation 


\section{International Journal for Research on Extended Education, Volume 3/2015}

\section{Content}

Editorial

\section{FREE CONTRIBUTIONS}

Lena Boström, Assar Hörnell \& Marie Frykland

Learning Environments at Leisure-Time Centres in Sweden:

A Comprehensive Survey of Staff Perceptions

Jesica Siham Fernández, Angela Nguyen \&Regina Day Langhout

"It's a puzzle!" Elementary School-Aged Youth Concept-Mapping

the Intersections of Community Narratives

\section{Lars Holm}

Researching Extended Schooling Ethnographically -

With Danish All-Day Schools as Examples

Fuyuko Kanefuji

Evaluation of School-Based After-School Programs in Japan:

Their Impact on Children's Everyday Activities and Their Social and Emotional Development

Joshua F. Lawrence, Briana M. Hinga, Joseph L. Mahoney \&

Deborah Lowe Vandell

Summer Activities and Vocabulary Development:

Relationships Across Middle Childhood and Adolescence

Lisa H. Schwartz, Daniela DiGiacomo \& Kris D. Gutiérrez

Designing "Contexts for Tinkerability" With Undergraduates and

Children Within the El Pueblo Mágico Social Design Experiment

Kym Simoncini, Jennifer Cartmel \& Amy Young

Children's Voices in Australian School Age Care:

What do They Think About Afterschool Care?

\section{AUTHOR INFORMATION}

Authors 


\title{
Researching Extended Schooling Ethnographically - With Danish All-Day Schools as Examples
}

\author{
Lars Holm
}

\begin{abstract}
The aim of this article is to discuss and demonstrate how ethnographic-oriented research might contribute to broadening the research interest in extended education. Extended education might be seen as a societal investment in education. This perspective calls for different kinds of school effectiveness research that generates useful and relevant knowledge about how and to what degree extended schooling effects academic achievements seen from a general societal perspective. Extended education might, however, also be seen as a new school strategy - as a new way of organizing pupils, teachers and parents everyday-life. Ethnographic-oriented educational research seeks to examine how an implementation of extended education in a local area impacts actors' everyday-life and generates new discourses and struggles over values and concepts in education. This is illustrated through an analysis of the dynamics created by the implementation of all-day schooling in a specific residential area in Denmark.
\end{abstract}

Keywords: all-day schools, ethnographic-oriented research, Denmark, cooperation between school and parents, cooperation between school-teachers and kindergarten-teachers.

\section{Introduction}

In the last decades educational policy in many European countries seems to have been highly influenced by two parallel processes. The first is the concept "the knowledge-society" that indicates a post-industrial époque in which production and distribution of knowledge is thought to be central for maintaining and/or increasing the gross domestic product. The second is the growing political attention to supranational educational agencies and organizations (e.g. PISA, TIMMS, EU, OECD) measurements, strategies and concepts. Together these two processes have created a situation in and around education in many European countries in which a pursuit of improved academic achievements in international comparisons, such as PISA, and in various nationwide measurements has become central. The general strategy in many countries has been an extension or supplementation of traditional educational institutions and their forms of instruction ${ }^{1}$.

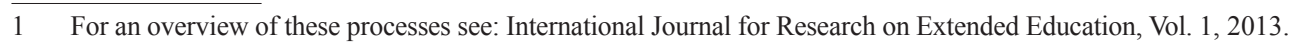


The all-day schools in Denmark and, for example, Germany share the same background. In both countries international PISA-measurement showed unsatisfying national results in the public schools, and in both countries one of the political initiatives taken to improve schooling was to develop all-day schools. Another similarity in both countries is the multiple objectives beyond improved academic achievement such as improved societal integration and increased cooperation between school and parents (Holm, 2008). However, being embedded in different national educational traditions and political landscapes also creates substantial differences in how allday schools are conceptualized, implemented and interpreted by key actors. The all-day schools in Denmark are compulsory, and the distinction seen for example in Germany between compulsory and open forms of all-day schooling ("gebundene und offene Ganztagsschulen") has never been an issue on the Danish political agenda. Another substantial difference is the strong tradition in Denmark for school leisure-time centers ("Skolefritidsordninger/SFO"), which has been highly affected by the establishment of all-day schooling

Implementation of all-day schools and other forms of extended schooling results in different processes depending on the historical and political contexts and circumstances in which extended schooling is introduced. Drawing on a concept from discourse analysis (Laclau \& Mouffe 2002) the term "all-day schools" might be characterized as an "empty" or "floating signifier" that functions as a symbolic common denominator for a wide variety of projects. This makes it relevant to examine all-day schools as a complex societal enterprise that is locally situated and given its form and content by different groups of actors' behaviors and attitudes towards school, learning, socialization and society. Theoretically speaking, this research approach is inspired by policy-ethnography (Shore \& Wright, 1997; Levinson \& Sutton, 2001). The use of this theoretical lens means the policy is understood as something that is simultaneously negotiated in different social arenas, and something that is actively acquired by the various actors who might support or reject a project like the all-day school. This approach represents a shift away from an understanding of education policy as a linear, top-down process and from the implicit idea that the implementation of concrete policy initiatives is a more or less passive transfer to a given target group. Policy ethnography is a form of extended, "multisited ethnography" (Marcus 1995) that combines ethnographic interview and observational material, background history and current and historical policy analysis. These multiple categories of data make it possible to shift the analytic focus between analysis at the micro-level (personal experiences and interactions), the meso-level (organizational and institutional factors) and macro-level (government structures and political-economic forces). (Gustafsson, 2003; Acosta \&Volk, 2001). In this article the focus is on some of the processes and dynamics on the micro- and meso-level that emerged as central issues when the all-day schools were implemented in a housing area in Denmark.

This article is based on the results of a three-year research project in a residential area named "Vollsmose" of the municipality of Odense in Denmark. The general aim of the research project was to examine how this "first wave" of extended schooling was constructed and understood by key group actors, and how these groups of actors behaved in response to the extended schooling. In the following, I focus on two different processes around the implementation of the extended schooling - which was 
termed "all-day schools" in the Danish context. The first is the process around the integration of the leisure-time teachers in the school, and the other is parents' understanding of the all-day schools. The central question to be examined and analyzed in relation to the first process is the dynamics when two different professional understandings of children, pedagogy and schooling are expected to merge in a common project: the all-day school $^{2}$. In relation to the second process the focus is on how parents and school interpret and react to the establishment of all-day schooling in a specific local area. When the all-day schools were implemented in the three schools in the area a number of different local issues emerged in the three schools. Discussions about how the extended time should be used, about the general organization of the extended school day, about the distribution of lessons and playtime, and about the time for lunch breaks and other breaks took on different shapes from school to school (Holm \& Valentin, 2007). However, two issues emerged as more general in all three schools, and became central in the national discourse about all-day schools at that time. The integration of the leisure-time teachers in the all-day schools caused a more general and national discussion about the role of teachers and school leisure-time teachers in school and about the relation in schools between "learning" and "play" (Holm, 2010). The parents' reaction to the all-day-school in Vollsmose was a loud protest that was covered by national media and gave reason to more general discussion for and against all-day schools in general and brought parents into focus as central actors in relation to implementation of all-day schools (Holm \& Valentin, 2007).

\section{The First Wave of Extended Schooling in Denmark}

The first all-day schools in Denmark were established in 2006 in four municipalities in Denmark in areas with a high concentration of ethnic-minority students (Holm \& Valentin, 2007) $)^{3}$ - so-called "disadvantaged residential areas" or "ghetto areas". These housing areas are, according to the criteria of the Ministry of Welfare, defined as areas where at least $40 \%$ of the residents receive benefits, and at least $40 \%$ are migrants and descendants from non-Western countries (Socialministeriet, 2006).

Vollsmose is an area of northeastern Odense that has approximately 10.000 residents. The three district schools in the local area have around 1200 students in total, of which $90 \%$ are ethnic minorities. When the all-day school started in 2006 more than 500 students and 80-90 school teachers and leisure-time teachers were involved. The three all-day schools in Vollsmose in the municipality of Odense were established with an eight-lesson ${ }^{4}$ school day by means of an application for dispensation from the Danish Law on primary and lower-secondary schools $\S 16$ part 3, which states that the longest teaching period for early-schooling students must not exceed

As a consequence of the all-day schools leisure-time centers were closed or reduced substantially.

3 In Denmark the term "all-day school" is also used to describe schools for children with behavioral problems or special psychological conditions.

4 The term lesson describes in a Danish context a specific time unit that consists of 45 minutes' teaching and 15 minutes' playtime. 
six lessons in a school day. A central theme in the applications from the schools to the Ministry for Children and Education is that the all-day school is justified and needed due to the special conditions that apply to the students in these specific areas. In the applications from the three schools that applied to become all-day schools the students in the residential area are characterized as children who are not "linguistically, socially and behaviorally at the age-appropriate level", and as children in need of better school results (Holm \& Valentin, 2007). Thus, the arguments for all-day schools are related to general deficiencies and a lack of academic success among a particular group of students living in a particular residential area.

\section{The Empirical Data}

The empirical basis for the examination and analysis of the cooperation between school-teachers and leisure-time teachers is three months of fieldwork a year over a period of three years. The fieldwork took place at all three schools in three selected focus classes from 0 . to 2 . grade. This diachronic perspective made it possible to identify and analyze changes in practices and attitudes in the all-day schooling project. More specifically, the fieldwork has consisted of classroom observation, informal conversations with school-teachers and leisure-time teachers and participation in teacher meetings at the school. With regard to the cooperation between school and home the empirical basis for the analysis are informal conversations with parents, observations during meeting at schools and parent-teachers meetings. However, during the research process it became clear that the specific language situation in Vollsmose made it difficult to create a situation in which a somewhat equally matched and open dialogue was possible. It would lead to obvious problems in terms of a representative sample if the interviews were conducted only with parents who could and would speak Danish. In order to overcome this substantial methodological issue - which relates both to being an "outsider" (Goffman, 1959) and to not speaking the parents preferred language, I involved an "insider" to conduct semi-structured research interviews with Arabic-speaking parents of children in the three focus classes. My research assistant was multilingual, speaking both Danish and Arabic, lived in Vollsmose and had been a student at one of the all-day schools.

\section{$4 \quad$ The Cooperation Between School Teachers and School Leisure-Time Teachers}

Until 2014 the weekly number of lessons from grade 0 to grade 3 in the Danish primary school has typically been between $20-25$ lessons. The school was thus basically a "half-day school" for the younger pupils. But more than $80 \%$ of the younger children also attend school leisure-time centers in the afternoon (Thorsen \& Danø, 2006). The school leisure-time centers are organizationally a part of the school with 
their own facilities and their own staff. In most cases the leisure-time centers are situated in a separate building but on the same premises as the school. In contrast to the school, the school leisure-time centers are not free of charge. Parents pay a fee for each of their children attending the school leisure-time center.

In Denmark the school teachers and the school leisure time teachers are educated into two different types of pedagogy. In the educational practice and in the academic and professional discourse in Denmark there is a sharp distinction between school-pedagogy and leisure-time pedagogy (Broström, 2010; Højholdt, 2009). The pedagogy of teacher training is basically a didactical tradition with a focus on school subjects and curriculum. Teaching is seen as a process in which the teacher orchestrates a situation that makes it possible for the child to acquire knowledge, skills and competences. The pedagogy of leisure-time is based in developmental psychology and represents a tradition in which a child's development is understood as something that advances through play and other forms of practical activities and in interaction with other children and adults. The main objective for the leisure-time teacher is upbringing and caregiving, and upbringing is seen as a social-pedagogical organization of social interaction, in which the child, through its own activities, acquires norms, attitudes and behaviors. These different theoretical understandings, described here in very generalized terms, represent two different understandings of children and childhood with great impact for the practices and expectations in the two institutions. In the school discipline is expected and required and the child is regarded as a pupil who has to learn. In contrast to this, the school leisure time centers are characterized by an ideal or ethos of freedom in which the child is regarded as a child or as a being in its own right.

When the all-day schools were established in Odense in 2006 with 40 lessons a week it reduced the need for the school leisure-time centers dramatically and all or most of the leisure-time teaches were mowed from the school leisure-time center to the school. This meant that school teachers and leisure-time teaches were challenged with developing the all-day school in cooperation. Due to the integration of leisure time teachers in the school and due to more teacher resources given to the all-day school there were typically two teachers in the classes in more than $50 \%$ of the lessons, and quite often (but not always) a leisure-time teacher and a school teacher were together in the classroom (Holm, 2010).

The analysis of the cooperation between school teachers and leisure time teachers in the three schools revealed interesting patterns and practices that basically did not relate to the different educational backgrounds of school teachers and leisure-time teachers. Cooperation in teaching can be organized in many different ways. Creese (2005) makes a distinction between a "partnership mode" and a "support mode". A "partnership mode" is characterized by a common planning of the teaching, by both teachers working in cooperation towards the same subject aims and by both teachers having a number of different roles in teaching. In a "support mode" there is a clear distribution of roles. One teacher administrates the class and the subject aims, while the other teacher has a function as support for individual pupils.

The fieldwork revealed that the "support mode" was the dominant way to cooperate no matter who it was that cooperated - be it school teachers, or school teacher and leisure-time teacher, or leisure time teachers. There was clearly a prevailing 
consensus in the three all-day schools that cooperation in the classroom meant that one teacher took a special responsibility for one or a few pupils in the classroom typically the weakest or most difficult pupils in the class. The teacher taking on the role of "support-teacher" could either be a school teacher or a leisure-time teacher, and the teacher responsible for administrating the class could also be a leisure-time teacher or a school-teacher. Thus, the integration of the leisure-time teacher in the all-day school did not result in "a fusion of horizons" (Arkoudis, 2003, p.162) in which new and common aims and practices develop through a mutual interpretation of a common task founded in different epistemological understandings of childhood and schooling. In the first year the three all-day schools appeared to be a quantitative extension of the "half-day" school - "school as usual", but now with more support to the weakest pupils.

This demonstrates that bringing two different professional epistemologies together cannot be expected to automatically result in unification and qualitative change. The leisure-time teachers were newcomers in the school, and the extended school day was divided into lessons that mostly took place in classrooms. This physical organization of the all-day school - and the name of the project - indicated "school as usual" and thus legitimized a predominance of expectations of a school-pedagogy and of schooling. This context made it difficult - not to say impossible - for the leisure time teachers to argue for an understanding of childhood not based in traditional school logics.

However, after the first year of the all-day schools many teachers found that 8 lessons a day was overload for the younger children, and extended schooling consisting only of more lessons was seen as an unsatisfying way of implementing allday schools. This issue was repeatedly on the agenda at meetings in the schools and discussions about the all-day school seemed to give more space to reflections on leisure-time pedagogy than previously. In the three schools much effort and much creativity were put into attempts to combine play and learning in order to move away from "traditional" teaching. After one year with the basic concept "more school" one of the all-day schools changed the structure to school-like before lunch and leisure-time-center oriented after lunch (Holm, 2010). But the traditional basic logic of schooling in which adults are in charge of organizing social activity for pupils was not and could not be abandoned. From a child's perspective this meant that the previous change in pedagogy in the transition from school to leisure time center - from the "discipline of the school" to the "freedom of the leisure-time center" - did not take place anymore.

What gradually became evident for many school teachers and leisure-center teachers in the all-day school was that a combination of play and learning understood within the theoretical frameworks dominating school pedagogy and leisure time center pedagogy were incommensurable epistemologies. In some cases this understanding of the all-day school project made school-teachers and leisure-time teachers quit their job in the all-day schools and apply for jobs in contexts without all-day schooling.

All in all, the data reveals that the idea of integration of the school-leisure time teachers disturbed and challenged more traditional ways of thinking schools as places for teaching and learning, and the bringing together of different professions with 
different theoretical frameworks for understanding children and schools were clearly a potential source of conflict and contradictions.

\section{Parents' Reactions and Interpretation of the All-Day Schools}

Increased cooperation between schools and parents appears as an explicit aim in the all-day school applications from the three schools. In an ethnographic-oriented perspective this makes it highly relevant to examine how this group of actors reacted to the establishment of the all-day school. Hence, the analytical focus is directed towards the actions of the parents and their interpretation of the all-day schools. Insight into this might both shed light on the processes around the all-day school and on more general positions, norms and values among parents in relation to their children's schooling.

Based on observation from parent-teacher meetings, among other things, the fieldwork revealed that the parents in the area are very engaged in their children's schooling and education, and they place great importance on their children doing well at school. Success at school, not least the mastery of the Danish language, is thought to pave the way to higher education, social progression and success in later life. It is an internationally well-documented phenomenon that ethnic-minority parents are generally very aware and engaged in their children's education (Bouakaz, 2007). In light of this, schooling and education is a central meeting place between ethnic-minority parents and central education-policy actors at the local level.

The following analysis of parental perspectives draws on Freebody and Ludwig (1995) who use an approach in which discursive positions and theoretical understandings that are primary in various actors' perspectives is seen in relation to the school's function. If some actors, for example, consider the school's main task to be to equip students with particular academic competencies, then their discursive position is related to the education system's skill-development function. If the school's primary function is thought to be socialization via the regulation of children's time at school and home, then the actors' discursive position is related to the regulatory function.

It is a key element in the applications for the all-day schools that the students are defined as being "delayed" compared to the average Danish student at the same age, and therefore it is central for the all-day schools to give students "the opportunity to achieve the same academic level as students at the other schools in the municipality of Odense" as it is expressed in one of the applications (Holm \& Valentin, 2007). It is thus the education system's skill-development function that is foregrounded. The foremost means to achieving this goal is to expand the teaching hours in early schooling to 40 lessons a week. This indicates a quantitative temporal logic that is based on the assumption that more time at school leads directly to better academic achievement. Furthermore, the all-day schools in Odense are characterized by a departure from the Danish school system's traditional premise that the time children 
spend in school should gradually increase according to their grade, and (implicitly) according to the child's biological age and cognitive development (Holm \& Valentin, 2007). The extended school day in the three schools was only introduced in early schooling making the relationship between biological age and time spent at school a very visible trait of the all-day schools.

At parents' meetings and in the press the parents strongly criticized the all-day schools, although they were generally very engaged in their children's schooling. The parents' critique was based on a range of perspectives that were mostly related to the school's regulatory function. At numerous well-attended parents' meetings the all-day schools were the subject of often heated discussions, in which the legitimacy of the all-day schools was brought into question. Some parents pointed out that older students would benefit more from an extended school day than those in the early schooling, and other parents felt that the all-days school would have a negative influence on the child's childhood because a longer school day reduces the amount of time children can be with their friends, participate in sports activities and develop their interests. Either the parents were of about the idea that an extended school day leads to better academic achievement, or they did not focus on this in their interpretation of the all-day school.

Observations from meetings and interviews with parents clearly indicate that most parents had a sociologically oriented view of time. Time is perceived as a resource that can be negotiated between different social actors, and having control over time is seen as a manifestation of social control (Holm \& Valentin, 2007). From this perspective the all-day school appears to regulate time and fill it with content - not just for the students, but also for the families. When a mother expressed her perception of the all-day school by saying in a loud voice at a parents' meeting "You are taking our children away from us", it demonstrates that the school's regulatory function is in the foreground of this parents' interpretation of the all-day school.

The departure from the traditional temporal logic of the Danish school system is interpreted by many parents as an intensified institutional regulation of ethnic-minority families' lives rather than a qualitative improvement of school services. Thus, some parents view the all-day school as a kind of "replacement family" (Kolbe et al., 2009), wherein the school takes on a greater role in the socialization of the children, thereby reducing the family's role. Some parents interpret this as offensive and as indicating that they - in contrast to average "Danish" parents - are not considered to have the social, cultural and linguistic capital that is required to socialize their children. One specific reason for this interpretation was that the all-day schools were constructed to be homework-free schools. This meant that the all-day schools shift the responsibility for homework to the school. Some parents felt that an important function has been taken away from them, that they were not given enough opportunity to support their child's academic development. One of the mothers formulated her point of view as such: "Children should have homework to do at home so that parents can assist in helping and developing their child. At the moment, we cannot be part of it because the children do not bring their books or homework home". Homework clearly has an important symbolic role in many parents' perception of their parental roles and in their view of the school enterprise. The fact that homework plays an important role in how the school is interpreted - and that it can be a significant 
marker of difference between traditional Danish schools and independent "ethnic" schools - is illustrated by a student who explained that her father has told her that she would be transferred to an independent Arabic school "where there is homework".

The examples above all demonstrate that the regulatory function of the school appears to be the main interpretive position among the group of parents in this area. To a great extent, their interpretation is related to the departure of all-day schools from the traditional temporal logic in Danish schools. The extended school day is also viewed as an extended socialization on the part of the school, which disempowers the parents to a certain extent and interferes with their ability to plan activities for the children's free time or to do homework with their children. This interpretive position leads to a discourse with a strong opposition between the ethnic-minority parents on one side and the local district schools and the municipality of Odense on the other: Although the parents, the schools and the municipality all attach great importance to the academic success of ethnic-minority students, there does not seem to be a broad consensus among the parents with regard to the all-day schools in Vollsmose.

The fieldwork in the three schools revealed that the categorization, legitimization and temporal logic of the all-day schools in Odense have led to a dynamic among parents that represented oppositional norms and values regarding time, learning and responsibility. The parents respond critically to the quantitative increase in the amount of time children spend at school as well as to their children being categorized as "not at an age-appropriate level". The parents also interpret the all-day school as a form of intensified regulation and feel that it invalidates the family's cultural and linguistic capital. Although the critique from the parents was more pronounced in the first year of the all-day school, the introduction of the all-day school in Vollsmose appears to be a process that is wrought with conflict, in which opposition between groups of parents and school as an institution becomes actualized and intensified. Furthermore, the introduction of the all-day school has provoked and escalated discussions about which school parents want for their children and which values and norms they want to invest into them.

\section{The Second Wave of Extended Schooling}

The three all-day schools in Vollsmose analyzed in this article were evaluated in a report from October 2012 together with 9 other all-day schools placed in "disadvantaged residential areas" (Rambøll, 2012). It was a central conclusion in the report that there was no significant relation between the all-day schooling and the academic achievement of the pupils in national tests (Rambøll, 2012, p. 2). In other words: the first wave of extended schooling did not confirm the expectations to extended schooling about improved academic achievements. It was, however, underlined in the report that it was difficult to draw final conclusions about the effects of extended schooling concerning academic achievements. The result was an average based on data from the 12 schools, and more detailed analysis showed an increase in academic achievements in five schools, no substantial change in two schools, and a decrease 
in academic achievement in five schools (Rambøll, 2012). It was further emphasized that the extended schooling could have other un-examined positive or negative effects for schooling beyond what could be measured through the national tests (Rambøll, 2012). In general the report stated that the foundation of the evaluation was too weak to draw final conclusions about all-day schooling.

However, extended schooling - or all-day schools - for all children were put on the political and public agenda in 2012/2013 when the Minister of Education revealed an ambitious plan for a school-reform with extended schooling - often talked about as an all-day school. The proposal quickly generated an intense discourse pro et contra. A central component in this discourse was about "play and learning". In the often heated and extensive debate about all-day schools for all children it was emphasized by the proponents that new ways of combining play and learning should play a central role in the extended schooldays. Examples demonstrating how to combine play and learning were discussed and made accessible on the homepage of the ministry (http://nynordiskskole.dk). These examples basically reveal a didactic epistemology: practices for learning curriculum while playing. The didactic epistemology was also central in the political and academic reasoning for the extended schooling. The necessity of the all-day school was closely related to a need for better PISA-results; to a need for children delivering better academic results in different specific school subjects according to national and international measurement of individual children's subject skills. Finally the dominant position of the didactic epistemology is made evident by the fact that most teachers in the all-day schools would be school-teachers trained in a didactic epistemology.

The arguments against the all-day school were primarily related to the epistemology of leisure time pedagogy. It was emphasized that the all-day school would result in a "schoolification" of childhood in which children's play - understood as an autonomous social, and child-generated activity - would be heavily reduced or even disappear, and that this would do harm to childhood and to the development of independent children. Childhood researcher Erik Sigsgaard's main argument against the extended schooling related to broader issues of socialization and had the headline: You don't learn to live life at an institution (Sigsgaard, 2013). A well-known Danish author, Jakob Stegelmann, argued from a more psychological point of view and characterized the all-day school as an assault on children and childhood that would traumatize a whole generation of children (Stegelmann, 2013).

In general the pro et contra discourse in relation to the second wave of extended schooling was centered around the same clusters of arguments and logics that were also put forward in relation to the first wave of extended schooling. What did not seem to be questioned was, for example, the assumptions behind the school reform - that extended schooling would result in an increase in academic achievements and that increased academic achievements is a necessary condition for an ongoing increase in gross national product due to the competitive nature of the world market (Laursen \& Holm, 2011).

In august 2014 the new Danish school-reform with extended schooling was implemented for all school children (Weirsøe \& Holm-Pedersen 2014). It is a central aim of the reform to increase the scores in the national tests in literacy and mathematics and to reduce the number of pupils with bad results in the national tests. 
The central means to reach these and other aims such as increased social equality is extended schooling. 30 lessons a week for children in grade 0 to grade 3.33 lessons a week for children in grade 4 to grade 6 , and 35 hours a week for children in grade 7 to grade 9. Not only are the means the same in relation to the first and second wave of all-day schools. The multi-professional character of the school is also a similarity. In the second wave of the all-day schools leisure-time teachers and other personnel are given supporting teaching functions and are allowed to have full responsibility for a class of pupils without a school teacher being present. Compared to the legal regulation around the first wave of extended schooling this is an extension of the leisure-time teachers' role in the school. Differently to the first wave of all-day school the traditional temporal logic of the Danish school system, in which the number of lessons a week increases according to children's age, is reinstalled in the second wave of all-day school. Time will show if this second wave of all-day schools will have more success in reaching its ambitious aims concerning academic achievement, and time will also tell which types of research, with which central research questions, will examine and document the complexity around the second wave of all-day schools in Denmark.

\section{$7 \quad$ Concluding Remarks}

In this article I have argued for a research approach to extended schooling that is ethnographically oriented and inspired by policy ethnography. I would like to argue, that such a research endeavor might be a relevant supplement to the more effect-oriented research in extended schooling. A central strength in an ethnographic-oriented research approach is the local and situated character of the research and the inclusion of actors' interpretations and actions in relation to a given social enterprise. As it has been demonstrated in this article an analysis of the cooperation between school teachers and leisure-time teachers in the all-day schools in Vollsmose is not only of local interest. It contributes to our general knowledge on the challenges and possibilities for constructive and fruitful collaboration between different professions in relation to extended education - a research field that needs to be more closely examined, as Schüpbach and von Allmen (2013) convincingly argue, based on the understanding that multiprofessional collaboration seems to be a central component in extended education.

The analysis of the locally situated dynamics around extended education in Vollsmose has revealed conflicts, norms and values about schooling, pedagogy and family life that might be valuable for the development of school strategies and dialogue in local areas but also for our general understanding of the processes extended education might generate. In many western European countries it is central to schooling, and not least to extended schooling, that it should reduce social inequality and strengthen societal integration. At the same time schooling and academic achievement are more than ever seen in a national competitive perspective. Better academic achievements - through extended schooling - are given the highest priority in the political discourse in a way that does not seem to leave much space for dialogue with 
the actors who are bringing the extended education to life in their everyday practices at school. This might result in interpretations and actions that are counterproductive to the intention towards increased equality and integration. The complex, unforeseeable and locally situated processes around all-day schools or other forms of extended education make it highly relevant to direct research interest towards all the groups of actors involved in constructing and creating extended education by asking how extended education in a local context impacts the everyday life of children, parents, teachers and other central actors.

\section{References}

Acosta, M. D., \& Volk, D. (2001). Literacy policy and literacy in the classroom: what ethnography teachers us. In: G. Walford (Ed.), Ethnography and Education Policy. Studies in Educational Ethnography, Volume 4 (pp. 11-41). New York: Emerald Group.

Arkoudis, S. (2003). Teaching English as Second Language in Science Classes. Incommensurate Epistemologies. Language and Education, 17(3), 161-173.

Bouakaz, L. (2007). Parental involvement in school. What hinders and what promotes parental involvement in an urban school? Malmö: Lärarutbildningen i Malmö.

Broström, S. (2010). SFO som arena for læring. [SFO as arena for learning] In: T. Ankerstjerne (Ed.), SFO og fritidspaedagogik - fortid, nutid og fremtid. [SFO and leisure-time pedagogy. Past, present and future]. København: Dafolo.

Creese, A. (2005). Teacher Collaboration and Talk in Multilingual Classrooms. Clevedon: Multilingual Matters.

Freebody, P., \& Ludwig, C. (1995). Everyday literacy practices in and out of schools in low socio-economic urban communities. Brisbane, Australia: Centre for Literacy Education Research.

Goffman, E. (1959). The Presentation of Self in Everyday Life. New York: Doubleday.

Gustafsson, J. (2003). Integration som text, diskursiv och social praktik. En policyetnografisk fallstudie av mötet mellan skolan och förskoleklassen. [Integration as text, discoursive and social praxis. A policy ethnographic case study of the meeting between school and kindergarten]. Göteborg: Göteborg Studies in Educational Sciences 199.

Holm, L. (2008). Die Kooperation zwischen Ganztagsschulen und Eltern in Dänemark: Herausforderungen und Möglichkeiten. In: D. Bosse, I. Mammes \& C. Nerowski (Eds.), Ganztagsschule. Perspektiven aus Wissenschaft und Praxis. Erlangen: University of Bamberg Press.

Holm, L. (2010). Svært, men muligt at skabe pædagog-lærersamarbejde. [Difficult, but possible to create collaboration between schoole-teachers and leisure-time teachers]. Liv i skolen, 3, 24-28.

Holm, L., \& Valentin, K. (2007). Heldagsskolen som uddannelsespolitisk initiativ. Første statusrapport 2007-2008. [All-day schools as education policy initia- 
tive. First status report 2006-2007]. Available at http://www.dpu.dk/om/larsh [11.09.2014]

Højholdt, A. (2009). Den tvcerprofessionelle praktiker. [The multiprofessional practioner]. København: Hans Reitzels Forlag.

Kolbe, F. U., Reh, S., Fritzsche, B., Idel, T.-S., \& Rabenstein, K. (Eds.) (2009). Ganztagsschule als symbolische Konstruktion. Fallanalyse zu Legitimationsdiskursen in schultheoretischer Perspektive. Wiesbaden: Verlag für Sozialwissenschaft.

Laclau, E., \& Mouffe, C. (2002). Det radikale demokrati.[The radicale democracy]. Copenhagen: Samfundslitteratur.

Laursen, H. P., \& Holm, L. (2011). Migrants and literacy crises. Journal of Applied Language Studies, 5(2), 3-16.

Levinson, B. A. U., \& Sutton, M. (2001). "Introduction: Policy as/in Practice". In M. Sutton \& B. A. U. Levinson (Eds.), Policy as Practice. Towards a Comparative Socio-Cultural Analysis of Educational Policy. Westport, Conn.: Ablex Publishing.

Marcus, G. E. (1995). Ethnography in/of the world system: the emergence of multi-sited ethnography. Annual Review of Anthropology, 24, 95-117.

Rambøll (2012). Evaluering af heldagsskoler. Rapport. [Evaluation of all-day schools. Report].

Schüpbach, M., \& von Allmen, B. (2013). Swiss National Report on Research on Extended Education. International Journal for Research on Extended Education, 1(1), 18-30.

Shore, C., \& Wright, S. (1997). Policy: a new field of anthropology. London: Routledge.

Sigsgaard, E. (2013). Forsker om heldagsskoler: Man laerer ikke at leve livet på en institution. [Researcher about all-day schooling: You don't learn to live life at an institution] Available at: http://www.dr.dk/Nyheder/Indland/2013/03/04/223756. htm [11.09.2014].

Socialministeriet (2006). Den almene boligsektors fremtid. [The future of the social housing sector]. Copenhagen: Ministry of Social Affairs and Integration.

Stegelmann, J. (2013). Heldagsskole er et overgreb på børn. [All-day schools is an assult on children]. Available at: http://politiken.dk/debatindlæg/ECE1956838/ heldagsskole [11.09.2014]

Thorsen, K. M., \& Danø, T. (2006). SFO - mellem skole- og fritidspædagogik. [SFO - between school- and leisure-time pedagogy]. Uddannelse 2. København: Undervisningsministeriet.

Weirsøe, M., \& Holm-Pedersen, P. (2014). Skoler forandrer reformer - sjældent omvendt. [Schools change reforms - seldom the other way around]. Asterix, June, $20-23$. 